\title{
Attitudes towards refugees in Russia, Kyrgyzstan, Lebanon and Saudi Arabia
}

\author{
C.A. DeCoursey ${ }^{1}$, Boris Naimushin ${ }^{2}$, Hidayet Tuncay $^{3} \&$ Maria Stepanova ${ }^{4}$ \\ ${ }^{1}$ College of the Marshall Islands, Republic of the Marshall Islands \\ ${ }^{2}$ New Bulgarian University, Sofia, Bulgaria \\ ${ }^{3}$ Girne American Univerity, Cyprus \\ ${ }^{4}$ St. Petersburg Polytechnic University, St. Petersburg, Russia \\ Correspondence: C.A. DeCoursey, Social Sciences and Humanities, College of the Marshall Islands, PO Box \\ 1258 Majuro, Republic of the Marshall Islands MH. Tel: 692-625-3394. Email: DrChristinaAnn2015@mail.com
}

\author{
Received: March 3, 2017 Accepted: March 21, $2017 \quad$ Online Published: April 19, 2017 \\ doi:10.5539/ass.v13n5p116 URL: https://doi.org/10.5539/ass.v13n5p116
}

\begin{abstract}
As refugee flows have increased, western attitudes towards them have become conflicted. Attitudes towards refugees in non-western and in Muslim nations are rarely studied, though these nations accept most refugees. This study of attitudes towards refugees among tertiary students in the Kingdom of Saudi Arabia (KSA), Lebanon, Russia and Kyrgyzstan used Appraisal and content analysis frequencies and co-frequencies. Results showed that the Lebanese realised greater affect, possibly due to their experience of refugees. More generally, nationality shaped attitudes more than religion, tertiary students favour technocratic solutions by government actors despite realistically estimating the challenge, and while students critically analyse the problems created by refugee inflows, they retain a nativist stance and seem unaware of the optics and politics of this stance.
\end{abstract}

Keywords: attitudes towards refugees, borders, Appraisal analysis, content analysis

\section{Introduction}

Western nations receiving refugees fleeing the Syrian civil war are debating their commitment to their humanitarian obligations to receive and shelter refugees. This debate reflects the unprecedented scale of displacement and the ructions of the neoliberal western world order, and has called into question national identities, and shaped political leadership. The Syrian refugee crisis is often taken as a precursor to the anticipated refugee flows which will accompany future climate change. Tertiary students will be the decision-makers handling future refugee flows. This study explores the subjective attitudes and content they realise about Syrian refugees.

\section{Literature Review}

Contemporary western attitudes towards refugees are controverted, with popular anxieties contesting established policies. Muslims refugees have been linked with terrorism since 9/11, which has shaped the reception of Syrian refugees (Eid, 2014). Refugee health has highlighted the burden on welfare and medical systems (Fiddian-Qasmiyeh, Loescher, Long \& Sigona, 2014). Poor integration is one cause of western-born Muslim youth embracing jihad (Franz, 2015). The proliferation of jihadist groups has highlighted security issues (Lazaridis, 2016). Thus, the west has become reluctant to accept Muslim refugees, despite their 1949 Geneva Convention obligations.

Anxieties about refugees reflect popular xenophobia, but also problems arising six decades after Geneva, in a world that includes massive population flows due to globalisation, and extensive government responsibilities. The Geneva Conventions arose in a period of global carnage but not global migration or global media. EU governments must manage security and cost-sharing issues arising from free movement in the Schengen zone (Ahrens, Kelly \& Liempt, 2014). They must detect which global financial remittances support terrorists abroad (Zhirkov, Verkuyten \& Weesie, 2014). The media problematise issues such as gender tolerance (Joly, 2016). While governments articulate integration measures, social media amplifies negative views of the burden on western economies (Hervik, 2014). These new realities tend to undermine Geneva's moral vision (Winter, 2015). 
Western media, policy-makers and intellectuals now question whether they can accept refugees (Geiger \& Pecoud, 2010). These questions will not subside when peace comes to Syria: climate change will increase refugee flows in coming decades (Tacoli, 2009). Thus, it is important to study refugee reception.

Studies of western attitudes towards refugees are numerous (Davidov \& Meuleman, 2012). Many use cohort theory to explore how values change within groups and in response to contextual factors (O'Rourke \& Sinnott, 2006). Many connect economic stress with xenophobia (Strabac \& Listhaug, 2008). Some frame multiculturalism as bringing groups into conflict, challenging western nativity, and impacting social cohesion (Meuleman, Davidov, \& Billiet, 2009). Comparative studies have focused on European national attitudes. Yet Middle-eastern nations are managing the burden of the current crisis, with Lebanon and Jordan, not Geneva signatories, as well as Turkey, Egypt and war-torn Iraq, each taking more than a million refugees (UNHCR, 2016). Negative stereotyping exists among Muslim co-religionists, along the Sunni-Shi'i divide (Jones, 2007). Muslim women stereotype others by their hijab choices (Funk, 2015). Poor Muslim economic migrants face discrimination in wealthier Muslim countries (Jureidini, 2005). Saudi Arabs discriminate against Egyptians, Omanis, Bahrainis and Indians (Al-Rasheed, 2007); Iranian immigrants against non-Iranian Muslims (Moallem, 2005), and Turkish immigrants against non-Turks (Hopkins, 2016). Non-western nations such as Russia and Kyrgyzstan face the same challenges as western nations, in handling massive refugee flows. Thus, the attitudes of non-western and non-Muslim nations help us understand refugee reception more broadly, and forecast reception of future refugee flows.

In this study, attitudes were taken from Saudi, Lebanese, Russian and Kyrgyz university students, about refugees and border control. Data from these nations allows us to compare attitudes in several ways. Linguistically rich data builds a nuanced understanding of non-western attitudes. As Muslim-majority nations, KSA and Lebanon offer important contrasts. Oil wealth makes KSA the world's $20^{\text {th }}$ largest economy, where Lebanon ranks $91^{\text {st }}$ (IMF, 2015). KSA holds a central cultural position through the holy cities Mecca and Medina, and ensures social stability through policing (Niblock, 2004). Saudi youth under 25 are $45 \%$ of the population; $82 \%$ are urbanised, $35 \%$ receive tertiary education (Forstenlechner \& Rutledge, 2011). Lebanon is culturally diverse, with long-established Orthodox, Maronite, Catholic, Druze, Sunni and Shia communities (Cleveland, Laroche, Takahashi \& Erdoğan, 2014). With 19 official identities, Lebanon suffers from chronic sectarian tensions (Gordon, 2016). Beneficiaries of a globally-connected diaspora, Lebanese students are liberal and individualist (Kraidy, 2007). Lebanese and Saudi youth share elements of history, culture, language and religion, but not wealth, social or conflict experiences.

Russia is a western nation outside "the west", Kyrgyzstan a Muslim nation outside the Middle-East. They offer a valuable comparison with Saudi and Lebanese attitudes. Russia gained Kyrgyzstan in $19^{\text {th }}$ century wars with China, but Kyrgyzstan has reclaimed its identity since its 1991 independence (Kosmarskaya, 2014). Russia, spanning Europe and Asia, incorporates 185 official ethnicities, and 35 regional and 100 minority languages (Pavlenko, 2006). A Geneva Convention signatory, Russia is for $20^{\text {th }}$ century geopolitical reasons not included in what is termed "the west". Its centuries-old relationship with Middle-eastern nations developed separately (Donaldson \& Nogee, 2014). Kyrgyzstan's alliances are eastward-looking (Smallbone \& Welter, 2012). Russian majorities express negative attitudes towards Muslims (Mayda, 2006). Multiple varieties of Islam are accepted among Kyrgyzstan's 80 ethnic minorities (Montgomery, 2014). Russia ranks $73^{\text {rd }}$, Kyrgyzstan $181^{\text {st }}$ for GDP (IMF, 2015). Kyrgyz education is dynamic and reform-minded, with an internationalised public and private university system (Heynemandan \& Young, 2004). Russian youth distrust globalisation, and nostalgically imagine bygone soviet economic certainties (Pilkington, 2002). Reform in 2007 brought Russian in line with western educational standards (Shenderova, 2011). As western hegemony has declined, Russian and Central Asian stances on global issues have become more important globally (Tsygankov, 2016).

This article explores attitudes towards refugees among students in these four nations. All face refugee issues: Lebanon hosts Syrian refugees, KSA's war with Houthi rebels has generated an influx of Yemeni refugees across its uncontrolled Empty Quarter border, and Russia and Kyrgyzstan must manage jihadi returnees. Research questions addressed in this study included: How do non-western Muslims and extra-western westerners respond to closing borders to refugees? What attitudes are shared among the educated non-western Muslim and non-Muslim westerner youth who will become global entrepreneurs, professionals, media managers, policy-makers and business decision-makers in a decade's time? What are the impacts of being culturally central or less so, economically stronger or less so?

\section{Method}

Qualitative data was collected, and analysed in three ways. Appraisal analysis was used to identify 
frequently-realised attitudes. Content analysis was used to identify ideational element frequencies. Co-frequencies were identified.

\subsection{Participants}

In all, 338 university participants participated, including 96 Saudis, 81 Lebanese, 77 Russian and 84 Kyrgyz majors in medicine, engineering, business, media, communication and linguistics. All had the advanced English proficiency required for tertiary-level English instruction. Participants' other languages (Arabic, Russian, Turkish) are globally distributed, organising cultural identities for and being widely used in daily life across a large native geography and an extensive diaspora (Ruggles \& Silverman, 2009). Thus, while opinions realised will vary within national groups, participants in all locations will view their opinions as representing a global ecumene (Heller, 2003).

\subsection{Instrument}

Participants were asked to write a 200 -word personal opinion on the topic, "Should governments close their borders to refugees?" The prompt was brief, lexicogrammatically simple to avoid ambiguity, and phrased to elicit subjective attitude (Connor-Green, 2000). Giving a personal opinion is a familiar composition task, and elicits greater subjective language than conventional academic essays (Ramanathan \& Kaplan, 2000). Presentation of the topic was controlled by a protocol which limited teacher talk time to 3 minutes, required student group discussion, and required teachers to refrain from offering their own opinions (Morgan, 1996). Paragraphs were written out of class the following week, and emailed to researchers. Participants were instructed not to include scientific or historical information. Participation was optional and unassessed, to ensure elicitation of authentic opinion. Data collection occurred from December 2014 to May 2016.

\subsection{Appraisal Analysis}

Emotions are experienced by all people, and induce signature brain states (Pavlenko, 2002). They find morphosyntactic and lexical expression in all languages (Vakoch \& Wurm, 1997). Psycholinguistic models of the lexicogrammatical options for verbalising subjective attitudes articulate networks of semantic classes (Fontaine, Scherer \& Soriano, 2013). Derived from systemic functional linguistics, Appraisal is a linguistically delicate form of sentiment analysis used extensively in opinion-mining (Bednarek \& Martin, 2011). Appraisal taxonomises direct and indirect realisations of attitude into twenty-four semantic subcategories (Martin \& Rose, 2003). "Appraisal theories of emotions have gained widespread acceptance in the field of emotion research" (Kuppens, Van Mechelen, Smits, De Boeck, \& Ceulemans, 2007, 689). The Appraisal taxonomy enjoys increasing validity, as paradigms of emotion coming from the fields of linguistics and psychology have grown together. The Attitude system includes three sets: Affect, Judgment and Appreciation, articulated into semantic categories and subcategories (Scherer, Shorr \& Johnstone, 2001), as in Figure 1.

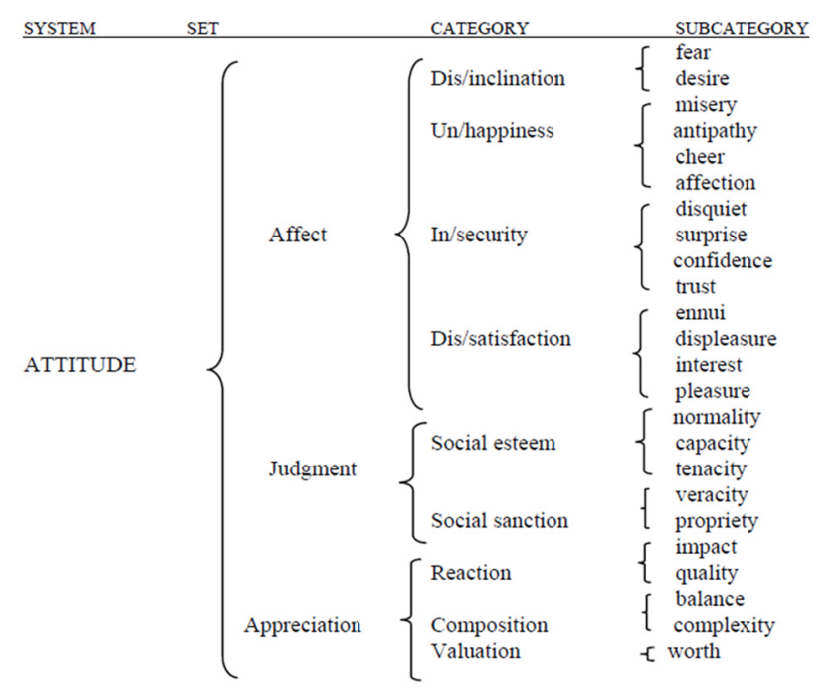

Figure 1. The Attitude system

When realising person opinions, people select their words from many available options (Halliday \& Matthiessen, 2004). Realisations are positive or negative. For example, "It is kindness and justice for countries to take in refugees" is positive where "government should never close their borders, it is not a solution to the problem" is negative. Realisations "diversify across a range of grammatical structures" (Martin \& White, 2005, 45). One may 
directly inscribe an emotion: "I want to help to refugees". Or, one may indirectly invoke an attitude by distributing its elements among the components of a sentence: "[ $t]$ he dedicated volunteers' action should remind the world that people have a responsibility and natural or human mental tendency to help" (Scherer, 2005).

Opinion data may be aggregated into a corpus, and attitudes tagged to identify regularities (Read \& Carroll, 2012). Text-tagging is widely-used in computational linguistics (Polanyi \& Zaenen, 2006). Text-tagging softwares use concordances of hierarchically-defined word classes created through supervised classification tasks, and sophisticated using statistical machine-learning techniques (Pang, Lee \& Vaithyanathan 2002). These programs efficiently sort corpus data into semantic classes (Bednarek, 2009). Subjective attitudes are easiest for software to identify (Oatley, Keltner \& Jenkins, 2006)). Because Appraisal integrates valence with direct/indirect realisations of the twenty-four semantic subcategories, it offers highly-defined results. This study used the software CorpusTool (CT), which builds in the Appraisal system networks (O'Donnell, 2008).

\subsection{Content Analysis}

Content analysis represents extensive corpus data as content element frequencies (Bryman, 2004). As units are derived from the corpus, these scores represent content precisely (Roberts, 1997). Coding the complete corpus ensures greater accuracy than sampling (Krippendorf, 2004). In this study, the four national subcorpora were fully coded, generating an emergent coding frame of frequently-realised content elements (Weber, 1985). Elements were mutually exclusive but not exhaustive, focusing on issues relating to refugees only (Denzin \& Lincoln, 2000). The clause formed the unit of analysis, as is conventional when analysing linguistic data (Babie, 2001). Element frequency scores used the clause as a boundaried coding unit. Cross-clause counts required lexical or syntactic connection to at least one distal clause (Carley, 1990). Clauses containing manifest content only were counted, with latent content disregarded (Stemler, 2001). In this corpus, the 5 content elements were each broken down into 5 subunits.

\subsection{Co-frequencies}

This study measured co-frequency as colligations of subunits with attitudinal word classes (Baayen, 2008). Collocations of lexical items were ruled out, as they often reflect idiomatic usage and morphosyntax, for example as "security" often collocates with "apparatus", and "man". Colligation of word classes supports interpreting co-frequencies as indexing culturally normative meanings (Hunston, 2002). The co-frequency measure used was Yule's $Y$, expressed as a value of -1 through +1 , where positive values indicate co-frequencies of varying strengths (Gries, 2008). Only co-frequencies greater than 0.50 , unlikely to be generated through morphosyntax or collocation, have been included (Chung \& Lee, 2001).

\subsection{Inter-rater and inter-coder reliability}

The corpus was tagged for Appraisal and coded for content by the lead researcher and a research assistant. Cohen's $\kappa$ was used to calculate inter-rater and inter-coder reliability, including percent-overall $(\mathrm{p}-\mathrm{o})$ and free-margin (f-m) (Lombard, Snyder-Duch \& Bracken, 2004).

\section{Data}

The prompt generated a corpus of 64776 words, in four national sub-corpora, as in Table 1. Attitude data in Table 2 is excerpted from Appendix A.

\subsection{Attitude data}

The subcorpora showed attitudinal differences. The Lebanese subcorpus was most positive, the Saudi most negative, though the range was moderate. Affect was infrequently realised, except in the Lebanese subcorpus. The Saudi corpus contained the most Judgment, which reframes emotions as evaluations of people and behaviours (Martin \& White, 2005). Judgments of esteem assess people and behaviours with reference to social norms; judgments of sanction realise issues of law, religious creeds, rules and regulations, duties and obligations (Hunston \& Thompson, 2000). For example, "It acted admirably and properly to give the refugees an education" reworks a positive feeling of pleasure as a positive evaluation of Saudi government actions. Positive Appreciations were found in all four, negative appreciations in all but the Russian subcorpus. The Kyrgyz corpus contained the most Appreciation, though the range was moderate. Appreciation reframes emotion as statements about the qualities of objects and events outside the self (Martin \& Rose, 2003). For example, "This is a very controversial issue" reworks a negative feeling of disquiet as a negative quality of the event.

\subsection{Frequently-realised Attitude categories and subcategories}

Realisations in six subcategories comprised $60-80 \%$ of all attitudes. Judgments were the most frequently-realised, across all subcorpora, particularly Judgments of capacity, positive and negative. Realisations of capacity express 
potentialities routinely instantiated in action (Panther \& Thornburg, 1999). Thus, in the Russian corpus:

[A] great amount of tolerance can't lead to anything good. We can bring the eample of modern situation in Europe...Many countries in EU suffer from this invasion for almost half a year and can't solve this problem, because they are afraid to be intolerant.

This participant views tolerance as incapable of solving the refugee problem. His past experiences of European tolerance ground his belief in his ability to make his claim.

Judgments of propriety ranked both positively and negatively in all subcorpora except the Lebanese. These realisations assert authorial stance towards a socially-accepted moral code (Scherer, Schoor \& Johnstone, 2001). Thus, in the Saudi corpus:

While it is noble to offer our support for free, I believe it will do very little benefit in the long run. They should work if they are not studying. But in some traditions they are allowed to sit.

This author adjudicates KSA governmental aid as positively appropriate ("noble") but negatively capable ("little benefit"). She adjudicates employment as positively ("should"), and unemployment as negatively appropriate ("allowed to").

Appreciations of quality ranked positively and negatively in the Saudi and Russian corpora, and positively in the Lebanese and Kyrgyz subcorpora. These rework emotion as attributes of a person or situation. For example, in the Saudi corpus: "Everyone knows it is a grim situation in Syria", "grim" reframes a personal feeling of misery as a quality of the civil war. In the Lebanese corpus: "It would be fantastic if we could give everyone a place, but Lebanon is a small country", "fantastic" reworks positive pleasure as a quality of an imagined solution to the refugee problem.

Normality is fundamental to all languages, as lexis and syntax reflect collective assumptions (Itkonen, 2008). Judgments of normality assess how well people and behaviours fit social norms. Normality ranked positively in the Saudi and Kyrgyz subcorpora, and negatively in the Saudi and Lebanese subcorpora. In the Kyrgyz subcorpus: "Normally, governments' responsibility is [to] give people of that country tranquil life", "normally" realises a positive belief of normal government provision for their people.

Appreciations of worth assess value. Positive and negative realisations of worth were found in the Saudi and Kyrgyz subcorpora. The Saudi comment, "Educating Syrians as doctors can have a valuable effect on their spirit in the difficult period of life, though restrictions on their movement may mean it is not useful in saving others", attributes both positive and negative worth to KSA governmental provision. Judgments of tenacity evaluate the degree of effort required. Positive and negative judgments of tenacity were found in the Russian and negative tenacity in the Lebanese corpus. In the Lebanese subcorpus, "If we keep on taking more people, we will not have anything ourselves" realises a negative judgment of tenacity. Reactions of impact rework emotion as attributes of events outside the self. Positive impact was found in the Russian and negative impact in the Lebanese and Kyrgyz subcorpora. In the Kyrgyz subcorpus: "Because of giving shelter to Syrian refugees, some horrible events are happening, bombings in cities", a negative emotional response is reframed as an attribute of a negative event. Positive and negative pleasure and cheer were found in the Lebanese corpus only ("I'm glad if Syrians can get away from the bombing, but it makes me mad too, because none of this should have happened").

Table 1. Size, sentence and clause, attitudinal density, valence and set values, for four national corpora

\begin{tabular}{|c|c|c|c|c|c|c|c|c|c|c|c|c|c|c|c|}
\hline \multirow[t]{2}{*}{ CORPUS } & \multirow{2}{*}{$\begin{array}{r}\text { WORDS } \\
\mathrm{N}\end{array}$} & \multirow{2}{*}{$\begin{array}{r}\text { SENTENCES } \\
\mathrm{N}\end{array}$} & \multirow{2}{*}{$\begin{array}{r}\text { CLAUSES } \\
\mathrm{N}\end{array}$} & \multirow{2}{*}{$\begin{array}{r}\text { ATTITUDE } \\
\mathrm{N}\end{array}$} & \multirow[t]{2}{*}{ ATT D } & \multicolumn{2}{|l|}{ POSITIVE } & \multicolumn{2}{|c|}{ NEGATIVE- } & \multicolumn{2}{|l|}{ AFFECT } & \multicolumn{2}{|c|}{ JUDGMIENT } & \multicolumn{2}{|c|}{ APPRECIATION } \\
\hline & & & & & & $\mathrm{N}$ & $\%$ & $\mathrm{~N}$ & $\%$ & $\mathrm{~N}$ & $\%$ & $\mathrm{~N}$ & $\%$ & $\mathrm{~N}$ & $\%$ \\
\hline Arabia & 19416 & 1203 & 2763 & 1229 & 63.30 & 681 & 55.41 & 548 & 44.59 & 208 & 16.92 & 696 & 56.63 & 325 & 26.44 \\
\hline Lebanon & 18119 & 1145 & 2589 & 1078 & 59.50 & 665 & 61.69 & 413 & 38.31 & 466 & 43.23 & 428 & 39.70 & 184 & 17.07 \\
\hline Russia & 15314 & 901 & 2117 & 982 & 64.12 & 592 & 60.28 & 390 & 39.71 & 273 & 27.80 & 475 & 48.37 & 234 & 23.83 \\
\hline Kyrgyzstan & 11927 & 783 & 1742 & 645 & 54.08 & 384 & 59.53 & 261 & 40.47 & 157 & 24.34 & 262 & 40.62 & 226 & 35.04 \\
\hline & 64776 & 4032 & 9211 & 3934 & 60.25 & 605.50 & 61.78 & 378 & 38.23 & 276 & 28.07 & 440.25 & 43.79 & 267.25 & 28.14 \\
\hline
\end{tabular}

Table 2. Frequently-realised semantic subcategories by rank and national subcorpora

\begin{tabular}{|c|c|c|c|c|c|c|c|c|c|c|c|}
\hline \multirow[t]{2}{*}{ RANK } & \multirow[t]{2}{*}{ SET-CATEGORY: SUBCATEGORY } & \multicolumn{2}{|c|}{ SAUDI ARABIA } & \multicolumn{2}{|c|}{ LEBANON } & \multicolumn{2}{|c|}{ RUSSIA } & \multicolumn{2}{|c|}{ KYRGYZSTAN } & \multirow[t]{2}{*}{$\mathrm{N}$} & \multirow[t]{2}{*}{$\%$ ATT } \\
\hline & & $+\mathrm{ve}$ & -ve & $+\mathrm{ve}$ & $-\mathrm{ve}$ & $+\mathrm{ve}$ & -ve & $+\mathrm{ve}$ & -ve & & \\
\hline 1 & Judgment-social esteem: capacity & 104 & 78 & 88 & 59 & 95 & 66 & 43 & 11 & 544 & 13.83 \\
\hline 2 & Judgment-social sanction: propriety & 137 & 116 & - & - & 114 & 89 & 51 & 33 & 540 & 13.73 \\
\hline 3 & Appreciations-reaction: quality & 82 & 92 & 51 & - & 91 & 83 & 19 & - & 418 & 10.63 \\
\hline 4 & Judgment-social esteem: normality & 93 & 95 & - & 67 & - & - & 70 & - & 325 & 8.26 \\
\hline 5 & Appreciations-valuation: worth & 69 & 53 & - & - & - & - & 25 & 24 & 171 & 4.35 \\
\hline 6 & Judgments-social esteem: tenacity & - & - & - & 52 & 62 & 44 & - & - & 158 & 4.02 \\
\hline 7 & Appreciations-reaction: impact & - & - & - & 48 & 40 & - & - & 68 & 156 & 3.97 \\
\hline 8 & Affect-Un/happiness: cheer & - & - & 93 & 57 & - & - & - & - & 150 & 3.81 \\
\hline 9 & Affect-dis/satisfaction: pleasure & - & - & 108 & 30 & - & - & - & - & 138 & 3.51 \\
\hline & & & & & & & & & & 2600 & 66.09 \\
\hline
\end{tabular}




\subsection{Content element and subunit frequencies}

Of 9,211 clauses in the four subcorpora, 8,003 contained content. Five frequently-occuring elements were identified: (1) problems caused by refugees, (2), ethical issues, (3) government obligations, (4) interpretations of refugees and (5) solutions. Four subunits were identified for each, and frequency scores obtained (see Appendix B). Differences between participant groups were evident, as in Figure 2. The Lebanese subcorpus had the most distinct profile, focusing on ethical questions over problems and government responses. The Saudi subcorpus focused strongly on ethical questions, and most on government. The Kyrgyz subcorpus focused most on interpreting refugees as persons, defining the problem and seeking solutions. The Kyrgyz and Russian profiles were similar to each other, with the Russian subcorpus focused more on government than ethics. The Lebanese and Saudi profiles focused on problems, solutions and interpretations.

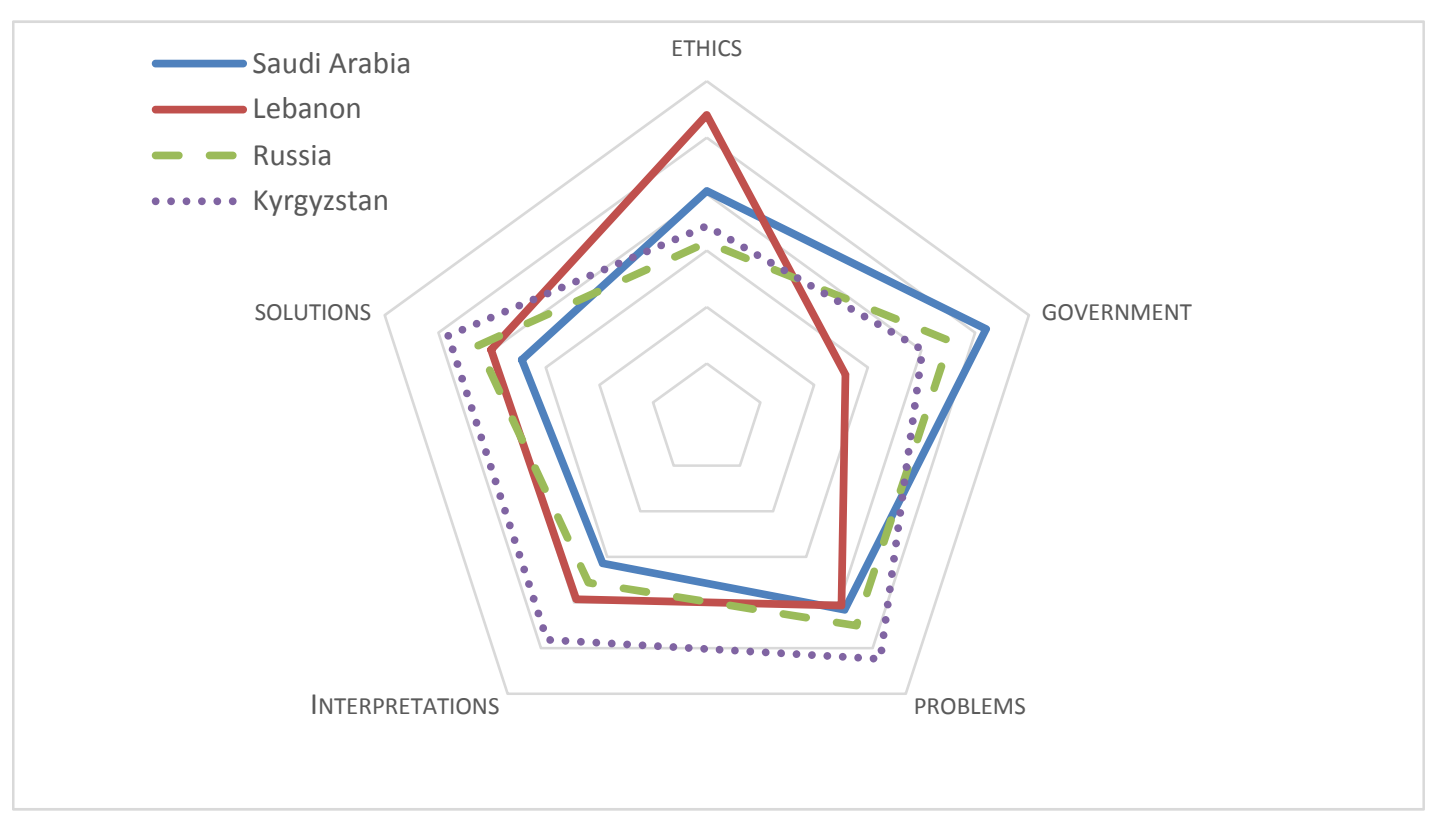

Figure 2. Content element realisations for four national subcorpora

All subcorpora had similar profiles for interpretations of refugees as people, and problems and solutions identified. Realisation frequency in these categories seemed to vary inversely with wealth. Kyrgyzstan, with a GDP $181^{\text {st }}$ in the world, had the highest values. Lebanon, with a GDP $91^{\text {st }}$, and Russia $73^{\text {rd }}$, had the next-highest values. Saudi, with the world's $20^{\text {th }}$ highest GDP, had the lowest values.

\subsection{Inter-rater and inter-coder reliability}

Inter-rater and inter-coder scores were calculated (Freelon, 2010), as in Table 3.

Table 3. Inter-rater and inter-coder reliability scores for four national corpora

\begin{tabular}{ccccc}
\hline corpus & \multicolumn{2}{c}{ inter-rater } & \multicolumn{3}{c}{ inter-coder } \\
\hline & $\mathrm{p}-\mathrm{o}$ & $\mathrm{f}-\mathrm{m}$ & $\mathrm{p}-\mathrm{o}$ & $\mathrm{f}-\mathrm{m}$ \\
Saudi Arabia & 0.873 & 0.844 & 0.835 & 0.817 \\
Lebanon & 0.896 & 0.862 & 0.857 & 0.821 \\
Russia & 0.856 & 0.829 & 0.831 & 0.808 \\
Kyrgyzstan & 0.882 & 0.854 & 0.870 & 0.845 \\
\hline
\end{tabular}

These values are robust, and not attributable to chance.

\subsection{Subunit-attitude co-frequencies}

The most frequently-realised subunit across all four subcorpora was (5a), closing borders and limiting numbers and kinds of refugees granted entry. While a majority of participants $(314=92.90 \%)$ considered both pros and cons, clauses about closed outnumbered those about open borders. Concerns mentioned in all subcorpora included territorial integrity, undocumented persons, costs (guards, administration), and crime (smuggling drugs, weapons, sex-slaves). A Saudi participant wrote: "Borders are usually [+normality] closed. People don't [-propriety] just walk in if they want." A Kyrgyz participant wrote: 
Territory is one of the main[+normality] and the most important[+normality] immediate constituent of each country. Hence, safety of borders is point of honor[+propriety] of every nation. If military cannot protect[ + propriety] boundary it means country does not stand[-normality] on its own two feet.

This subunit co-occurred with positive (KSA 0.63, Kyrgyzstan 0.59) and negative normality (KSA 0.64, Kyrgyzstan 0.51 ), and positive (KSA 0.57 , Russia 0.68 , Kyrgyzstan 0.53 ) and negative propriety (KSA 0.72 , Russia 0.62, Kyrgyzstan 0.58).

Refugee crime (2d) was the second most-frequently realised subunit, including robbery, brawling, and organised crime. A Russian participant wrote: "Some refugees under the pretext of [-propriety] saving his life penetrate into the territory of other countries, and then begin to plunder [-propriety] houses". Sexual assault (2c) was frequently-enough mentioned to be its own subunit. A Kyrgyz participant wrote: "in Germany, the government of that country allowed[+propriety] refugees to pass through borders and the result was shocking[-propriety]. Instead of being grateful,[-propriety] they caused mass riots[-propriety] and raped[-propriety] some women." Subunit $2 \mathrm{~d}$ co-occurred with positive (KSA 0.68 , Russia 0.50 ) and negative propriety (KSA 0.61, Russia 0.57, Kyrgyzstan 0.53).

Terrorism (1d) was third most-frequently realised. Participants discussed terror attacks in Istanbul, France, Germany, UK and Belgium. Some acknowledged negative stereotyping. A Kyrgyz participant wrote:

$[T]$ here were a lot of $[-n o r m a l i t y]$ explosions by terrorists. Mostly, the terrorists were with Islamic origin. So, there emerged an odd convention[-normality] about them that every[+normality] Muslim can $[+$ capacity] do terror.

Some explained terrorism as a psychological consequence of becoming a refugee. A Lebanese participant wrote: "You don't start out a terrorist, but you can[+capacity] become one due to unfair hardships of that life". This subunit (1d) co-occurred with positive (Kyrgyz 0.57) and negative normality (Saudi 0.53), and positive (0.63) and negative $(0.60)$ capacity in the Lebanese subcorpus. Participants in all subcorpora asserted that terrorists were part of refugee populations. Mentions of judicial penalties (5c) for crime and terrorism were frequent enough to be a separate subunit.

The obligation of receiving governments to assess refugee claims (3b) was fourth most-frequently realised. Participants in all subcorpora accepted that some refugees would be rejected or deported. A Saudi participant wrote: "Our government should[+propriety] strictly control the numbers entering, and limit[-capacity] where they can[-capacity] live, and according to what jobs are needed[+capacity]." Assertions that no nation could solve the refugee problem, and that governments had an ethical obligation to prioritise citizen rights, were frequent enough to be defined as separate subunits $(5 \mathrm{~d}, 3 \mathrm{~d})$. A Lebanese participant wrote:

Our government has to[+capacity] organise Syrians to provide their own schools and doctors, as in the Palestinian refugee camps. This way, Lebanese who can now hardly[-capacity] take a place in university because of so many Syrians, can[+capacity] get their own education.

Subunit 3 b co-occurred with positive (Russia 0.76 ) and negative propriety (KSA 0.65 ), and positive (KSA 0.60, Russia 0.56 , Kyrgyzstan 0.58 , Lebanon 0.61 ) and negative capacity (KSA 0.57, Lebanon 0.54). Participants in all subcorpora viewed refugees as imposing costs, which governments should control. A Russian participant wrote: "more refugees means more welfare (unemployment benefits, social housing, food stamps, etc) and thus more taxes." Healthcare and education were the most frequently-mentioned resources participants cited as requiring protection for nationals.

Assertions that refugees migrate to the EU for money (4b) was the fifth most-frequently realised, with terms such as "Harrods refugees" and "pseudo-refugees" used. A Lebanese participant wrote: "They come here, but most want to go to Europe because they can [+capacity] get good allowances. You can't [-capacity] get anything, even from the UN here". A Russian participant wrote: "The problem arises because there is a rumor that in Europe is provided high quality [+normality] of life for everyone". A Saudi participant wrote: "These Arabs run to Europe. And why is this? We can[+capacity] answer that they will not get the same[-normality] money if they run to Arab countries." This subunit (4b) co-occurred with positive (KSA 0.55, Russia 0.62, Kyrgyzstan 0.59) and negative capacity (KSA 0.65 , Lebanon 0.53 , Russia 0.60 ), and positive (KSA 0.66 ) and negative normality (Russia 0.55 , Kyrgyzstan 0.61 ). The view that refugees do not want to work was frequent enough to be defined as its own subunit (4d), as was the case for the view that refugees do not want to integrate (4c). A Lebanese participant wrote: "Syrians always think they own Lebanon. But they follow their own customs. Soon there is no Lebanon." Participants in all subcorpora frequently asserted the view that governments should condition acceptance of refugees on employment with limited benefits (5b). 
The view that refugees cause social stress (1a) particularly overcrowding and housing competition, as well as (1b) unemployment of citizens, were $6^{\text {th }}$ and $7^{\text {th }}$ most frequently mentioned. A Lebanese participant wrote: "How can we build our economy when we have as many[-normality] Syrians? They do the same[-normality] job but half[-normality] the pay, so our people lose jobs." Russian participants wrote: "[R]efugees of another culture always[-normality] cause tension[-impact]", and "If the refugees refuse to accept the culture of the countries, countries should not accept refugees". Subunit 1a co-occurred with negative normality (Russia 0.65 , Kyrgyzstan 0.55 ) and negative impact (Lebanon 0.62). Anxiety over a loss of cultural identity (1c) and government obligation to preserve existing social norms, particularly language and religion (3c) were frequently-enough realised to be defined as separate subunits.

Understanding that refugees seek safety (4a) was eighth-most frequently-realised, compassionate interpretations of refugees (2a) ninth-most, and acknowledgement of an ethical obligation to provide food and shelter (2b) twelfth-most. A Kyrgyz participant wrote: "Every[+normality] human being wants to live in safety and peace. Refugees from Syria do the same[+normality]." A Russian participant wrote: "We are all[+normality] human and whatever happen as human beings all[+normality] people should help each other in hard time[-normality] without paying attention to their race, religion, nation etc." A Lebanese participant wrote: "War is the most terrible[-impact] thing that can befall a person...We must offer simple[+quality] food and place." The view that wealthy nations should financially support refugees was frequently-enough realised to form a separate subunit (3a). A Kyrgyz participant wrote: "I'm not saying that all[-normality] countries should open their borders to refugees but those governments that are able to support them". Participants rarely identified specific nations, more often acknowledging the difficulties faced by EU nations. A Russian participant wrote:

Taxpayers of the richest[+quality] and most developed[+quality] countries as Germany, Norway, Switzerland are not able to maintain hundreds of thousands refugees. Many of them want to obtain European citizenship and don't plan to come back home. In my opinion such a situation could have a destructive[-impact] effect for European economy in the nearest future. European civilization is not so stable[-quality] ideologically and religiously as it looks like. If Europeans want to safe their material well-being they need to close country borders to refugees.

The subunit 4a co-occurred with positive (Russia 0.57 , Kyrgyzstan 0.51 ) and negative normality (Russia 0.52 ), and positive (Russia 0.51, Lebanon 0.64) and negative qualities (Russia 0.50). The subunit 2a compassion co-occurred with negative impact (Lebanon 0.62 ). The subunit $2 \mathrm{~b}$ provision of food and shelter co-occurred with positive quality (Lebanon 0.56) and pleasure (Lebanon 0.67).

\section{Discussion}

Attitude data shows that refugees evoke little emotion among educated non-western Muslims and extra-western westerners. That Lebanon differed in this regard probably reflects its experience hosting 1.5 million Syrians in a tiny country. Appreciations of impact, high in the Lebanese subcorpora alone, are similar. Content analysis revealed that participants understand the refugee crisis to be about problems caused by refugees, the government's obligation to control them, possible solutions, negative stereotypes of refugees as people, and ethical issues. Across all four subcorpora, university students frame their response to these problems and solutions in terms of capacity, propriety, normality and worth. Capacity was most frequently realised, co-occurring with multiple subunits; handling terrorism, critically assessing refugee documentation and managing status claims, administering housing, health, education and other benefits, and excluding those who wanted not to work or to claim benefits unfairly. These show that participants focused on technocratic solutions to the refugee problem. Yet their use of capacity shows reification. Less than $1 \%$ were semantically-bleached as in "I can see your point" (Sweetzer, 1988), or constrained existential uses, as in the Russian corpus, "such measures [closing borders] can only have populist meaning"). Few parsed the meaning of the attributed capacity, as did this Kyrgyz participant:

$[R]$ easons may be different diseases, religious differences or sometimes the hidden motives of refugees like terrorism (it is also possible), but the government can control them. For example, Slovakia receives only those refugees who are in Christian religion.

Most used universal circumstantial modal constructions, which do not restrict the degree of possibility (Portner, 2009), as in the Kyrgyz subcorpus: "[P]ut limitations for immigrants and create strict and serious rules for new comers in which our government can control any unexpected accidents". These realisations valorised national or foreign governments as agents, in a totalising, simplistic manner. This is surprisingly unrealistic: where Saudis may, Russians, Kyrgyz and Lebanese seem less likely to have a high estimate of their governments' efficacy. While a technocratic approach to problem-solving has merit, and attribution of government efficacy will 
moderate with work experience, this data identifies the lack of emotional engagement as a significant problem, for refugee reception in non-western and Muslim nations.

Direct realisation of emotion is a reliable indicator of personal engagement, as it represents the self and its experience, as for example in the Lebanese subcorpus, "I feel their fear". But most attitudes in the other subcorpora used lexicalised constructions, which place distance between the self and the experience. Nominalised constructions reframe the experience of emotion metaphorically as a noun, as in the Saudi corpus: "I have a poor opinion of these refugees". Shared subjectivity aligns the author with a specific group perspective, as in the Saudi corpus, "everyone knows that they harass women". Typification subsumes emotional experience within the formality of a category, as in the Russian subcorpus "Refugees should understand that it isn't a chance to increase their quality of life; it's just a kind of charity". Conditional constructions rework emotion as a hypothetical or potential, as in the Kyrgyz corpus, "I think if the only thing refugees want is safety, they could stay in Turkey, but they go further to have social benefits that Turkey will not give". Projection puts the ideas into other voices, as in the Saudi corpus, "We see on the news, how they do not accept to work". This suggests that actual experience of refugees may be more salient than university education in ensuring a positive reception of refugees.

The most common stand-in for emotional was ethical engagement. Propriety was used most after capacity, co-occurring with border control, crime control, and documentation, though Lebanon was again an exception. The majority of these realisations were directly inscribed (in the Saudi corpus, "They should not[-propriety] take anyone who has committed a crime") rather than indirectly invoked (in the Russian corpus, "If a newcomer commits an offence or disturbs others by his or her very bad[-propriety] behavior, this person must be extradited"). This language dichotomises refugees into good and bad kinds, conditioning their fitness to receive assistance on their behaviour. It is understandable that participants criticise behaviours such as robbery and rape, and identify social problems associated with refugee populations. But their focus on these without a similar realisation of the obligation of care is troubling. While the $1951 \mathrm{UN}$ Convention, Article 1/F specifies serious crime as a reason for excluding persons from refugee status, refugees also have the right of non-refoulement, or return to territories in which their lives or safety are endangered, and of freedom of movement within the host nation (Foster, 2007). This highlights the necessity to teach refugee reception to tertiary students.

\section{Conclusion}

This study has produced four main conclusions. First, national identity shaped the attitudes realised more than religious or economic factors. The Lebanese corpus was most positive, the Saudi most negative. The Lebanese corpus had the greatest congruency, affect and ethics content, where co-religionists in KSA realised more propriety and government content. The economies of KSA, Russia and Kyrgyzstan are very different, and yet their attitudes were more similar to each other than to those of Lebanese participants. This suggests that personal experience is more significant than nationality, religion or economic status in shaping attitudes towards refugees.

Second, tertiary students' response to the refugee crisis lacks emotion. Participants in all subcorpora most frequently realised capacity, propriety, normality and worth. Positive judgments of capacity in all participant groups suggest a belief that it is possible to handle the crisis effectively, but these were contradicted by judgments of tenacity, suggesting participants correctly perceive the challenge, perhaps indicating that they compartmentalise experiential and cognitive sources of understanding. This conclusion is supported by the distinct qualities of the Lebanese corpus. Participants from wealthier nations, KSA and Russia, realised government-related content more frequently, and have more effective governments than Lebanon and Kyrgyzstan. Yet Kyrgyz and Russian co-frequencies of propriety and government-related content were more similar to each other than to the Lebanese corpus, again suggesting that it was Lebanese participants' experiences of refugees accounts for their different responses. High reification and low semantic bleaching also supports this view. Overall, this suggests that university students place excessive faith in technocratic solutions, unless they have contrary personal experience.

Third, tertiary students seem underprepared to respond to future refugee flows. They assert the propriety of defending borders and social systems against refugees whom they stereotype negatively as lazy and greedy troublemakers and terrorists. The most common co-frequency was normality, for closed borders. The second most frequent was refugee crime with negative propriety. Responses lack compassion, and reflect nativist self-interest, consonant with group threat theory. The Lebanese corpus was the exception to this, suggesting experience of refugees elicits compassion, and counters defensive stereotyping. As future leaders and decision-makers, they seem not to appreciate the politics and the optics of nativism. Moral leadership requires that compassion is expressed, and enacted, for both communities. A nativist reception may be read as prejudice, 
exclusion, selfishness, ineffectiveness or isolationism (Fiddian-Qasmiyeh, Loescher, Long \& Sigona, 2014). Refugee reception will retain political significance, as climate change increasingly shapes $21^{\text {st }}$ century politics.

Fourth, while students' focus on problem-analysis is valuable, critical thinking may not be sufficient to manage future refugee crises. Content analysis generated 20 subunits focused on practical challenges of refugee inflows, but only 5 focused on the ethical dimensions of the crisis. The relatively low realisation of solidarity with and compassion for refugees suggests contemporary students remain blind to their own positionality, which often undermines the reception of leaders and decisions. Cohort theory shows that attitudes change slowly, in response to changing contexts. This suggests the need to teach contemporary tertiary students greater critical awareness of nativism, emphasising the ethics and politics of national responses to refugee flows, but also teaching a critical awareness of positionality. The teaching of empathy and compassion has been extensively developed in healthcare contexts: these methods could be used more broadly in foundation year content, in order to prepare tertiary youth for a future in which refugees will become part of daily life.

This study has limitations. Sample size impacts the accurate representation of tertiary students' attitudes, particularly in the case of Russia, which has a large population. While the nations selected furnish useful comparisons, comparing mega-states such as Russia and micro-states such as Lebanon is difficult. This may be somewhat mitigated in the remaining four studies of hot-button social issues connected with refugees: contraception, employment, education and citizenship. These may provide a more accurate picture of non-western and Muslim attitudes.

\section{Acknowledgements}

The authors thank Dr. Irina Samarina of the Southern Federal University in Rostov-on-Don, Russia, and Dr. Zoya Asratyan of the Institute of Social Technologies of Naberezhnye Chelny in Tatarstan, Russia for their valuable assistance in data collection.

\section{References}

Al-Rasheed, M. (2007). Contesting the Saudi State; Islamic voices from a New Generation. Cambridge, Cambridge University Press.

Baayen, R. (2008). Analyzing Linguistic Data: A Practical Introduction to Statistics Using R. Cambridge: Cambridge University Press.

Babie, E. (2001). The practice of social research. Belmont, Wadsworth.

Bednarek, M. (2009). Dimensions of evaluation: Cognitive and linguistic perspectives. Pragmatics \& Cognition, 17(10), 146-175. DOI:10.1075/p\&c.17.1.05bed

Bednarek, M., \& Martin, J. (Eds) (2011). New discourse on language: Functional perspectives on multimodality, identity, and affiliation. Bloomsbury, UK.

Bryman, A. (2004) Social research methods. Oxford, Oxford University Press.

Carley, K. (1990). Content analysis. In Asher, R. (Ed.) The encyclopedia of language and linguistics. Edinburgh, Pergamom Press, 725-730.

Chung, Y. M., \& Lee, J. Y. (2001). A corpus-based approach to comparative evaluation of statistical term association measures. Journal of the American Society for Information Science and Technology, 52(4), 283-296. DOI:10.1002/1532-2890(2000)9999:9999<::AID-ASI1073>3.3.CO;2-X

Cleveland, M., Laroche, M., Takahashi, I., \& Erdoğan, S. (2014). Cross-linguistic validation of a unidimensional scale for cosmopolitanism. J. of Business Research, 67(3), 268-277, DOI:10.1016/j.jbusres.2013.05.013

Connor-Greene, P. (2000). Making connections: Evaluating the effectiveness of journal writing in enhancing student learning. Teaching of Psychology 27(1), 44-46. DOI:10.1207/S15328023TOP2701.10

Davidov, E., \& Meuleman, B. (2012). Explaining attitudes towards immigration policies in European countries: The role of human values. Journal of Ethnic and Migration Studies, 38(5), 757-775, DOI:10.1080/1369183X.2012.667985

Denzin, N. \& Lincoln, Y. (Eds.) (2000) Handbook of qualitative research. Thousand Oaks, Sage.

Donaldson, R. H., \& Nogee, J. L. (2014). The Foreign Policy of Russia: Changing Systems, Enduring Interests, 2014. Routledge, UK.

Eid, M. (2014). Perceptions about Muslims in western societies. In Eid, M. and Karim, K. (Eds.) Re-Imagining the Other. Palgrave Macmillan, US, pp. 99-119. 
Fiddian-Qasmiyeh, E., Loescher, G., Long, K. \& Sigona, N. (Eds.) (2014) Oxford Handbook of Refugee and Forced Migration Studies, Oxford University Press, Oxford.

Fontaine, J., Scherer, K., and Soriano, C. Eds. 2013. Components of emotional meaning: A sourcebook. Oxford University Press: Oxford.

Forstenlechner, I., \& Rutledge, E. J. (2011). The GCC's "demographic imbalance": Perceptions, realities and policy options. Middle East Policy, 18(4), 25-43. DOI:10.1111/j.1475-4967.2011.00508.x

Foster, M. (2007). International refugee law and socio-economic rights: Refuge from deprivation. Cambridge, Cambridge University Press.

Franz, B. (2015). Pop-jihadism: Why Young European Muslims Are Joining the Islamic State. Mediterranean Quarterly, 26(2), 5-20. DOI:10.1215/10474552-2914484

Freelon, D. (2010). ReCal: Intercoder reliability calculation as a web service. International Journal of Internet Science 5(1), 20-33.

Funk, J. (2015). Public expressions of Bosnian Muslim religiosity and lived faith: The cases of Friday prayer and hijab. In The Revival of Islam in the Balkans (pp. 204-221). Palgrave Macmillan UK.

Geiger, M., \& Pécoud, A. (Eds.) (2010). The politics of international migration management Palgrave Macmillan UK.

Gordon, D. C. (2016). The Republic of Lebanon: Nation in jeopardy. Routledge, UK.

Gries, S. (2008): Dispersions and adjusted frequencies in corpora. International Journal of Corpus Linguistics, 13(4), 403-437. DOI:10.1075/ijcl.13.4.02gri

Halliday, M., \& Matthiessen, C. (2004). An introduction to functional grammar (3rd ed.). Great Britain: Hodder Education.

Heller, M. (2003). Globalization, the new economy, and the commodification of language and identity. Journal of Sociolinguistics, 7(4), 473-492. DOI:10.1111/j.1467-9841.2003.00238.x

Hervik, P. (2014). Cultural War of Values: The Proliferation of Moral Identities in the Danish Public Sphere. In J. Tripathy, \& S. Padmanabhan (Eds.), Becoming Minority: How Discourses and Policies Produce Minorities in Europe and India (pp. 154-173). Sage, India.

Hopkins, P. (2016). Geographies of Muslim Identities: Diaspora, Gender and Belonging. Routledge, UK.

Hunston, S., \& Thompson, G. (2001). Evaluation in text: Authorial stance in the construction of discourse. Oxford, Oxford University Press.

Hunston, S. (2002). Corpora in Applied Linguistics. Cambridge: Cambridge University Press.

International Monetary Fund. (2015). World Economic Outlook. Retrieved from https://knoema.com/IMFWEO2016Apr/imf-world-economic-outlook-weo-april-2016

Itkonen, E. (2008). The central role of normativity in language and linguistics. In Zlatev, J. (Ed.) The shared mind: Perspectives on intersubjectivity, Amsterdam, John Benjamins, 279-305.

Joly, D. (Ed.). (2016). Scapegoats and social actors: the exclusion and integration of minorities in Western and Eastern Europe. Springer, UK.

Jones, T. (2007). Saudi Arabia's not so new Anti-Shi'ism. Middle East Report, (242), 29-32. http://www.jstor.org/stable/25164776

Jureidini, R. (2005). Migrant workers and xenophobia in the Middle East. Palgrave Macmillan, UK.

Kosmarskaya, N. (2014). Russians in post-Soviet Central Asia: more 'cold' than the others? Exploring (ethnic) identity under different sociopolitical settings. Journal of Multilingual and Multicultural Development, 35(1), 9-26. DOI:10.1080/01434632.2013.845195

Kraidy, M. (2007). Saudi Arabia, Lebanon and the changing Arab information order. International Journal of Communication, 1(2), 139-156. http://repository.upenn.edu/asc_papers/198

Krippendorf, K. (2004). Content analysis: An introduction to its methodology. Thousand Oaks, Sage.

Kuppens, P., Van Mechelen, I., Smits, D.J.M., De Boeck, P. \& Ceulemans, E. (2007). Individual differences in patterns of appraisal and anger experience. Cognition and Emotion, 21(4), 689-713 https://ppw.kuleuven.be/okp/_pdf/Kuppens2007IDIPO.pdf 
Lazaridis, G. (2016). Security, insecurity and migration in Europe. Routledge, UK.

Lombard, M., Snyder-Duch, J. \& Bracken C. (2004). Practical resources for assessing and reporting intercoder reliability in content analysis research projects. Retrieved from ils.indiana.edu/faculty/hrosenba/www/Research/methods/lombard_reliability.pdf

Martin, J. \& Rose, D. (2003) Working with discourse: meaning beyond the clause. London, Continuum.

Mayda, A. M. (2006). Who is against immigration? A cross-country investigation of individual attitudes toward immigrants. The review of Economics and Statistics, 88(3), 510-530. DOI:10.1162/rest.88.3.510

Moallem, M. (2005). Between warrior brother and veiled sister: Islamic fundamentalism and the politics of patriarchy in Iran. University of California Press.

Morgan, D. (1996). Focus groups as qualitative research. Sage, UK.

Meuleman, B., Davidov, E. \& Billiet, J. (2009) Changing attitudes toward immigration in Europe, 2002-2007: A dynamic group conflict theory approach. Social Science Research 38(2), 352-365, DOI:10.1016/j.ssresearch.2008.09.006

Montgomery, D. (2014). Towards a theory of the rough ground: merging the policy and ethnographic frames of religion in the Kyrgyz Republic. Religion, State \& Society, 42(1), 23-45, DOI:10.1080/09637494.2014.887265

Niblock, T. (2004). Saudi Arabia: Power, legitimacy and survival. Routledge, UK.

Oatley, K., Keltner, D. \& Jenkins, J. (2006). Understanding Emotions. Blackwell, Oxford.

O'Donnell, M. (2008). Demonstration of the UAM CorpusTool for text and image annotation. Proceedings of the ACL-08:LT Demo Session (Companion Volume) Columbus, Ohio, Association for Computational Linguistics, 13-16.

O'Rourke, K. \& Sinnott, R. (2006). The determinants of individual attitudes towards immigration. European Journal of Political Economy, 22(4), 838-861. DOI:10.1016/j.ejpoleco.2005.10.005

Pang, B., Lee, L., \& Vaithyanathan, S. 2002. Thumbs up? Sentiment classification using machine learning techniques. Proceedings of the 2002 conference on empirical methods in natural language processing. Philadelphia, Pennsylvania, USA.

Panther, K.U., \& Thornburg, L. (1999). The potentiality for actuality metonymy in English and Hungarian. In K. U. Panther, \& G. Raggen (Eds.), Metonymy in language and thought (pp. 333-351). Amsterdam, John Benjamins.

Pavlenko, A. (2002). Bilingualism and emotions. Multilingua, 21(1): 45-78. DOI:10.1515/mult.2002.004

Pavlenko, A (2006). Russian as a lingua franca. Annual Review of Applied Linguistics 26(1), 78-99, DOI:10.1017/S0267190506000055

Pilkington, H. (2002). Looking West? Cultural globalization and Russian youth cultures. Pennsylvania, Pennsylvania State University Press.

Polanyi, L. \&Zaenen, A. (2006). Computing attitude and affect in text: Theory and applications. Springer, USA.

Portner, P. (2009). Modality, Oxford: Oxford University Press.

Ramanathan, V., \& Kaplan, R. (2000). Genres, authors, discourse communities: theory and application for L1 and L2 writing instructors. Journal of Second Language Writing, 9(2), 171-191. DOI:10.1016/S1060-3743(00)00021-7

Read, J., \& Carroll, J. (2012). Annotating expressions of appraisal in English. Language resources and evaluation, 46(3), 421-447. DOI:10.1007/s10579-010-9135-7

Roberts, C. (Ed.) (1997). Text analysis for the social sciences: Methods for drawing statistical inferences from texts and transcripts. Mahwah, NJ, Erlbaum.

Ruggles, D., \& Silverman, H. (2009). (Eds.) Intangible heritage embodied. New York, Springer.

Scherer, K. R. (2005). What are emotions? And how can they be measured? Social science information, 44(4), 695-729. DOI:10.1177/0539018405058216

Scherer, K., Shorr, A., \& T. Johnstone. (Eds.) (2001). Appraisal Processes in Emotion: Theory, Methods, Research, Oxford University Press, Oxford. 
Shenderova, S. V. (2011). The Institutional Arrangement for Multi-Level Higher Education and Ways of Its Development in Russia. Economics of Contemporary Russia, 2(1), 123-134. Retrieved from https://www.researchgate.net/profile/Nadine_Burquel2/publication/272168796_Innovation_and_Transform ation_in_Transnational_Education_European_and_Russian_Joint_Study_Programmes/links/54dd16130cf28 a3d937891a9.pdf

Smallbone, D., \& Welter, F. (2012). Entrepreneurship and institutional change in transition economies: The Commonwealth of Independent States, Central and Eastern Europe and China compared. Entrepreneurship \& Regional Development, 24(3-4), 215-233. DOI:10.1080/08985626.2012.670914

Stemler, S. (2001). An overview of content analysis. Practical assessment, research and evaluation, 7(17), 137-146. http://PAREonline.net/getvn.asp? $\mathrm{v}=7 \& \mathrm{n}=17$

Strabac, Z., \& Listhaug, O. (2008). Anti-Muslim prejudice in Europe: Amultilevel analysis of survey data from 30 countries. Social Science Research, 37, 268-286. DOI:10.1016/j.ssresearch.2007.02.004

Sweetser, E. (1988). Grammaticalization and semantic bleaching. In Annual Meeting of the Berkeley Linguistics Society, 14(May), 389-405. DOI:10.3765/bls.v14i0.1774

Tacoli, C. (2009). Crisis or adaptation? Migration and climate change in a context of high mobility. Environment and urbanization, 21(2), 513-525. DOI:10.1177/0956247809342182

Thielemann, E., \& Armstrong, C. (2013). Understanding European asylum cooperation under the Schengen/Dublin system: a public goods framework. European Security, 22(2), 148-164, DOI:10.1080/09662839.2012.699892

Tsygankov, A. P. (2016). Russia's foreign policy: change and continuity in national identity. Rowman \& Littlefield, UK.

UN High Commission for Refugees (2016), "Syrian Regional Refugee Response”, Inter-agency Information-sharing Portal, http://data.unhcr.org/syrianrefugees/regional.php

Vakoch, D. \& Wurm, L. (1997). Emotional connotation in speech perception: Semantic associations in the general lexicon. Cognition \& Emotion, 11(4), 337-349. doi:10.1080/026999397379827

Weber, R. (1985). Basic content analysis. London, Sage Publications.

Winter, E. (2015). Rethinking Multiculturalism After its "Retreat" Lessons From Canada. American Behavioral Scientist, 59(6), 637-657. doi:10.1177/0002764214566495

Zhirkov, K., Verkuyten, M., \& Weesie, J. (2014). Perceptions of world politics and support for terrorism among Muslims: Evidence from Muslim countries and Western Europe. Conflict Management and Peace Science, 31(5), 481-501. doi:10.1177/0738894213510121

\section{Appendix A}

Frequently-realised Attitudinal subcategories by valence and rank

\begin{tabular}{|c|c|c|c|c|c|c|c|}
\hline \multicolumn{8}{|c|}{ SAUDI ARABIA } \\
\hline & POSITIVE & & & & & & \\
\hline RANK & SET & CATEGORY & SUBCATEGORY & EXAMPLES & $\mathrm{N}$ & $\%+$ & $\%$ ATT \\
\hline 1 & Judgment & social esteem & propriety & should, must, supposed to & 137 & 20.12 & 11.15 \\
\hline 2 & Judgment & social sanction & capacity & can, able to, know how to & 104 & 15.27 & 8.46 \\
\hline 3 & Judgment & social esteem & normality & usual, regular, common & 93 & 13.66 & 7.57 \\
\hline 4 & Appreciation & reaction & quality & lovely, fine, great & 82 & 12.04 & 6.67 \\
\hline 5 & Affect & in/security & trust & believe, expect, rely & 81 & 11.89 & 6.59 \\
\hline \multirow[t]{3}{*}{6} & Appreciation & valuation & worth & valuable, costly, merit & 69 & 10.13 & 5.61 \\
\hline & & & & & 562 & 82.53 & 45.73 \\
\hline & NEGATIVE & & & & & & \\
\hline RANK & SET & CATEGORY & SUBCATEGORY & EXAMPLES & & $\%-$ & \\
\hline 1 & Judgment & social sanction & propriety & shouldn't, wrong, mistake & 116 & 21.17 & 9.44 \\
\hline 2 & Judgment & social esteem & normality & too different, strange & 95 & 17.34 & 7.73 \\
\hline 3 & Appreciation & reaction & quality & awful, poor, down & 92 & 16.79 & 7.49 \\
\hline 4 & Judgment & social esteem & capacity & cannot, not able to & 78 & 14.23 & 6.35 \\
\hline 5 & Appreciation & valuation & worth & no purpose, not worth it & 53 & 9.67 & 4.31 \\
\hline 6 & Affect & in/security & confidence & uncertainty, worry & 45 & 8.21 & 3.66 \\
\hline
\end{tabular}




\begin{tabular}{|c|c|c|c|c|c|c|c|}
\hline & & & & & 479 & 87.41 & 38.73 \\
\hline \multicolumn{8}{|c|}{ LEBANON } \\
\hline & POSITIVE & & & & & & \\
\hline RANK & SET & CATEGORY & SUBCATEGORY & EXAMPLES & $\mathrm{N}$ & $\%+$ & $\%$ ATT \\
\hline 1 & Affect & dis/satisfaction & pleasure & glad, fun, pleased & 108 & 16.24 & 10.02 \\
\hline 2 & Affect & un/happiness & cheer & happiness, content, joy & 93 & 13.98 & 8.63 \\
\hline 3 & Judgment & social esteem & capacity & can, able to, could & 88 & 13.23 & 8.16 \\
\hline 4 & Affect & dis/inclination & desire & want, long for, need & 72 & 10.83 & 6.68 \\
\hline 5 & Judgment & social esteem & normality & usual, natural, normal & 67 & 10.08 & 6.22 \\
\hline \multirow[t]{3}{*}{6} & Appreciation & reaction & quality & amazing, great, fantastic & 51 & 7.67 & 4.73 \\
\hline & & & & & 479 & 72.03 & 44.43 \\
\hline & NEGATIVE & & & & & & \\
\hline RANK & SET & CATEGORY & SUBCATEGORY & EXAMPLES & & $\%-$ & \\
\hline 1 & Affect & un/happiness & misery & unhappy, heart breaking & 61 & 14.80 & 5.66 \\
\hline 2 & Judgment & social esteem & capacity & unable, cannot, incapable & 59 & 14.29 & 5.47 \\
\hline 3 & Affect & un/happiness & cheer & happiness, content, joy & 57 & 13.98 & 5.47 \\
\hline 4 & Judgment & social esteem & tenacity & weak, unreliable, fragile & 52 & 12.59 & 4.82 \\
\hline 5 & Appreciation & reaction & impact & horrible, awful, nasty & 48 & 11.62 & 4.45 \\
\hline \multirow[t]{2}{*}{6} & Affect & dis/satisfaction & pleasure & upset at, mad, angry about & 30 & 7.26 & 2.78 \\
\hline & & & & & 307 & 74.33 & 28.48 \\
\hline \multicolumn{8}{|c|}{ RUSSIA } \\
\hline & POSITIVE & & & & & & \\
\hline RANK & SET & CATEGORY & SUBCATEGORY & EXAMPLES & $\mathrm{N}$ & $\%+$ & $\%$ ATT \\
\hline 1 & Judgment & social sanction & propriety & should, must, ought & 114 & 19.26 & 11.61 \\
\hline 2 & Judgment & social esteem & capacity & can, able to, know how to & 95 & 16.05 & 9.67 \\
\hline 3 & Appreciation & reaction & quality & dramatic, peaceful & 91 & 15.37 & 9.27 \\
\hline 4 & Judgment & social sanction & tenacity & keep on, durable, sturdy & 62 & 10.47 & 6.31 \\
\hline 5 & Appreciation & reaction & impact & helpful, beneficial, relief & 40 & 6.76 & 4.07 \\
\hline \multirow[t]{3}{*}{6} & Affect & un/happiness & misery & happy, relaxed, soothe & 34 & 5.74 & 3.46 \\
\hline & & & & & 436 & 73.65 & 44.40 \\
\hline & NEGATIVE & & & & & & \\
\hline RANK & SET & CATEGORY & SUBCATEGORY & EXAMPLES & $\mathrm{N}$ & $\%-$ & $\%$ ATT \\
\hline 1 & Judgment & social sanction & propriety & not proper, wrong, bad & 89 & 22.82 & 9.06 \\
\hline 2 & Appreciation & reaction & quality & uncontrollable, tough & 83 & 21.28 & 8.45 \\
\hline 3 & Judgment & social esteem & capacity & cannot, don't know how & 66 & 11.15 & 6.72 \\
\hline 4 & Affect & in/security & confidence & unclear, timid, unsafe & 55 & 14.10 & 5.60 \\
\hline 5 & Judgment & social esteem & tenacity & stop, (not) continue & 44 & 7.43 & 7.57 \\
\hline \multirow[t]{2}{*}{6} & Affect & dis/inclination & fear & fear, fearful, afraid & 31 & 5.24 & 3.16 \\
\hline & & & & & 368 & 62.17 & 37.47 \\
\hline \multicolumn{8}{|c|}{ KYRGYZSTAN } \\
\hline & POSITIVE & & & & & & \\
\hline RANK & SET & CATEGORY & SUBCATEGORY & EXAMPLES & $\mathrm{N}$ & $\%-$ & $\%$ ATT \\
\hline 1 & Judgment & social esteem & normality & special, different, cool & 70 & 20.11 & 10.85 \\
\hline 2 & Affect & dis/satisfaction & pleasure & pleased about, content & 64 & 18.39 & 9.92 \\
\hline 3 & Judgment & social sanction & propriety & proper, right, real & 51 & 14.66 & 7.91 \\
\hline 4 & Judgment & social esteem & capacity & can, know how to, ability & 43 & 12.36 & 6.67 \\
\hline 5 & Appreciation & valuation & worth & best, valuable, worthwhile & 25 & 7.18 & 3.88 \\
\hline \multirow[t]{3}{*}{6} & Appreciation & reaction & quality & crazy, harsh, unkind & 19 & 5.46 & 2.95 \\
\hline & & & & & 272 & 78.16 & 42.17 \\
\hline & NEGATIVE & & & & & & \\
\hline RANK & SET & CATEGORY & SUBCATEGORY & EXAMPLES & $\mathrm{N}$ & $\%+$ & $\%$ ATT \\
\hline 1 & Appreciation & reaction & impact & appalling, horrible, awful & 68 & 19.54 & 10.54 \\
\hline 2 & Judgment & social sanction & propriety & wrong, mistaken, mustn't & 33 & 12.64 & 5.12 \\
\hline 3 & Affect & in/security & confidence & feel sure, definitely & 31 & 11.49 & 4.65 \\
\hline 4 & Appreciation & valuation & worth & futile, pointless, not worth & 24 & 9.58 & 3.88 \\
\hline 5 & Judgment & social esteem & capacity & cannot, isn't able to & 11 & 4.21 & 1.71 \\
\hline \multirow[t]{2}{*}{6} & Affect & dis/satisfaction & pleasure & angry, upset, fed up & 9 & 2.59 & 1.40 \\
\hline & & & & & 176 & 67.43 & 27.29 \\
\hline
\end{tabular}

This table presents values for the six most frequently-realised semantic subcategories, for each national subcorpus. Realisations of the other 18 subcategories together comprised 0.83 to $1.67 \%$ of all attitudes, cannot be considered to represent frequently-held attitudes, and thus have been excluded. 


\section{Appendix B. Content elements and subunits, ranked by frequency of mentions}

\begin{tabular}{|c|c|c|c|c|c|c|c|c|c|c|c|}
\hline \multirow[t]{2}{*}{ content element } & \multirow[t]{2}{*}{ subunits } & \multicolumn{2}{|c|}{ Saudi Arabia } & \multicolumn{2}{|c|}{ Lebanon } & \multicolumn{2}{|c|}{ Russia } & \multicolumn{2}{|c|}{ Kyrgyzstan } & \multirow[b]{2}{*}{ ave $\%$} & \multirow[b]{2}{*}{ rank } \\
\hline & & $\mathrm{n}$ & $\%$ & $\mathrm{n}$ & $\%$ & $\mathrm{n}$ & $\%$ & $\mathrm{n}$ & $\%$ & & \\
\hline \multirow[t]{5}{*}{$\begin{array}{l}\text { 1. problems } \\
\text { caused }\end{array}$} & (a) for citizens social stress & 37 & 1.63 & 172 & 7.32 & 73 & 3.95 & 145 & 12.34 & 6.31 & 6 \\
\hline & (b) for citizens: unemployment & 224 & 9.85 & 41 & 1.74 & 96 & 5.20 & 93 & 6.07 & 5.72 & 7 \\
\hline & $\begin{array}{l}\text { (c) for nation: loss of cultural } \\
\text { identity }\end{array}$ & 26 & 1.14 & 27 & 1.15 & 105 & 5.69 & 12 & 0.78 & 2.19 & 18 \\
\hline & (d) for nation: terrorism & 186 & 8.18 & 238 & 10.12 & 142 & 7.69 & 151 & 9.86 & 8.96 & 3 \\
\hline & & 473 & 20.80 & 478 & 20.33 & 416 & 22.54 & 401 & 26.17 & & \\
\hline \multirow[t]{5}{*}{ 2. ethical issues } & $\begin{array}{l}\text { (a) service: compassion for the } \\
\text { unfortunate }\end{array}$ & 41 & 1.80 & 232 & 9.87 & 76 & 4.12 & 85 & 5.55 & 5.34 & 9 \\
\hline & $\begin{array}{c}\text { (b) service: provision of basic food } \\
\text { and shelter }\end{array}$ & 59 & 2.59 & 180 & 7.66 & 58 & 3.14 & 47 & 3.07 & 4.12 & 12 \\
\hline & $\begin{array}{l}\text { (c) offence: sexual misconduct by } \\
\text { refugees }\end{array}$ & 98 & 4.31 & 46 & 1.96 & 74 & 4.01 & 79 & 5.16 & 3.86 & 13 \\
\hline & $\begin{array}{c}\text { (d) offence: crimes committed by } \\
\text { refugees }\end{array}$ & 263 & 11.57 & 177 & 7.53 & 82 & 4.44 & 52 & 3.39 & 10.18 & 2 \\
\hline & & 461 & 20.27 & 635 & 27.01 & 290 & 15.71 & 263 & 17.17 & & \\
\hline \multirow[t]{5}{*}{$\begin{array}{l}\text { 3. government } \\
\text { obligations }\end{array}$} & $\begin{array}{l}\text { (a) to refugees: wealthy nations } \\
\text { should take more refugees }\end{array}$ & 23 & 1.01 & 156 & 6.64 & 77 & 4.17 & 129 & 8.42 & 5.06 & 10 \\
\hline & $\begin{array}{c}\text { (b) to refugees: rigorous } \\
\text { assessment and selection of } \\
\text { refugees }\end{array}$ & 278 & 12.23 & 43 & 1.83 & 139 & 7.53 & 140 & 9.14 & 7.68 & 4 \\
\hline & $\begin{array}{l}\text { (c) to citizens: preservation of } \\
\text { existing social norms (language, } \\
\text { religion) }\end{array}$ & 94 & 4.13 & 26 & 1.11 & 118 & 6.39 & 16 & 1.04 & 3.17 & 16 \\
\hline & $\begin{array}{l}\text { (d) to citizens: priority for social } \\
\text { services (education, medical) }\end{array}$ & 196 & 8.62 & 79 & 3.36 & 84 & 4.55 & 23 & 1.50 & 4.51 & 11 \\
\hline & & 591 & 26.02 & 304 & 12.93 & 418 & 22.64 & 308 & 20.10 & & \\
\hline \multirow[t]{5}{*}{$\begin{array}{l}4 . \\
\text { interpretations } \\
\text { of refugees }\end{array}$} & $\begin{array}{l}\text { (a) empathetic: refugees want } \\
\text { safety }\end{array}$ & 33 & 1.45 & 165 & 7.02 & 57 & 3.09 & 156 & 10.18 & 5.44 & 8 \\
\hline & $\begin{array}{l}\text { (b) sceptical: refugees want to } \\
\text { become rich in the EU }\end{array}$ & 71 & 3.12 & 230 & 9.78 & 75 & 4.06 & 168 & 10.97 & 6.98 & 5 \\
\hline & $\begin{array}{l}\text { (c) sceptical: refugees do not want } \\
\text { to integrate culturally }\end{array}$ & 164 & 7.21 & 25 & 1.06 & 88 & 4.77 & 34 & 2.22 & 3.82 & 14 \\
\hline & $\begin{array}{l}\text { (d) sceptical: refugees do not want } \\
\text { to work }\end{array}$ & 89 & 3.81 & 42 & 1.79 & 109 & 5.90 & 11 & 0.72 & 3.06 & 17 \\
\hline & & 357 & 15.70 & 462 & 19.65 & 329 & 17.82 & 369 & 24.09 & & \\
\hline \multirow[t]{6}{*}{ 5. solutions } & $\begin{array}{l}\text { (a) security: control borders to } \\
\text { limit numbers entering, who enters }\end{array}$ & 202 & 8.89 & 197 & 8.38 & 211 & 11.43 & 187 & 12.21 & 10.23 & 1 \\
\hline & $\begin{array}{l}\text { (b) national: regulation of refugee } \\
\text { employment and benefits }\end{array}$ & 45 & 1.98 & 169 & 7.19 & 102 & 5.53 & 5 & 0.33 & 3.76 & 15 \\
\hline & $\begin{array}{l}\text { (c) refugee: judicial penalties for } \\
\text { refugee law-breaking }\end{array}$ & 92 & 4.05 & 35 & 1.49 & 66 & 3.58 & 48 & 3.13 & 3.06 & 17 \\
\hline & $\begin{array}{l}\text { (d) national: nations cannot solve } \\
\text { all refugee problems }\end{array}$ & 53 & 2.33 & 71 & 3.02 & 14 & 0.76 & 17 & 1.11 & 1.81 & 19 \\
\hline & & 392 & 17.24 & 472 & 20.08 & 393 & 21.29 & 191 & 12.47 & & \\
\hline & $\mathrm{N}$ content clauses & 2274 & & 2351 & & 1846 & & 1532 & & & \\
\hline
\end{tabular}

\section{Copyrights}

Copyright for this article is retained by the author(s), with first publication rights granted to the journal.

This is an open-access article distributed under the terms and conditions of the Creative Commons Attribution license (http://creativecommons.org/licenses/by/4.0/). 